\title{
Upper Oligocene lithostratigraphic units and the transition to the Miocene in North Belgium
}

\author{
MichiEL DUSAR $^{1 *} \&$ NoËL VANDENBERGHE ${ }^{2}$
}

${ }^{1}$ Royal Belgian Institute of Natural Sciences - Geological Survey of Belgium, Brussels, Belgium; mdusar@naturalsciences.be.

${ }_{*}^{2}$ Dept. Earth and Environmental Sciences, KU Leuven, Belgium; noel.vandenberghe@kuleuven.be.

* corresponding author.

\begin{abstract}
The presence of Chattian deposits in Belgium was confirmed in the early 20th century by correlation of their mollusc faunas with the type Chattian in Germany. Consequently, the Voort Formation in the Campine Basin and the Boncelles Sand on the northeastern Ardennes were established and assigned a Chattian age. Contacts with underlying Rupelian and overlying Burdigalian formations are marked by hiatuses, linked mainly to end-Oligocene Savian tectonics and reactivation of the Roer Valley Graben (RVG). On the Campine Block, only the lower part of the Chattian, the Voort Sand is deposited, increasing in thickness in the direction of the RVG and including a geophysically traceable clayey marker horizon allowing the mapping of this unit in the Campine Basin, into the Netherlands and even possibly link it to the hydrostratigraphic subdivision of the Chattian in the Lower Rhine Graben. Lithologically, these uppermost Paleogene Chattian deposits form the base of the Neogene sequence along the Southern Bight of the North Sea, characterised by predominantly glauconite-bearing sand. The Chattian sediments rapidly become thicker in the strongly subsiding RVG, resulting in a more continuous sedimentation with the development above the Voort Sand of a clay unit and another sand unit, forming together the Veldhoven Formation. In Belgium such sequence is only found in the RVG without biostratigraphic data. However, it can be demonstrated that lithostratigraphically this sequence is comparable to the better-studied Veldhoven Formation in the Netherlands where biostratigraphy revealed that the Veldhoven Formation grades into the Aquitanian to Burdigalian, crossing the Paleogene-Neogene boundary and separated from middle Miocene deposits by the Early Miocene Unconformity (EMU). It is proposed to harmonise Belgian and Dutch stratigraphic nomenclatures, making the more complete Veldhoven Formation applicable both in the Campine Basin and the Roer Valley Graben, and further north in the Netherlands. Within this scheme, the Belgian Voort Formation becomes the Voort Member as the lower part of the Veldhoven Formation, of which the middle Wintelre clayey and upper Someren sandy members are only recognised in the graben.
\end{abstract}

KEYWORDS: Chattian, Campine Basin, Roer Valley Graben, Lower Rhine Graben, Voort Formation, Veldhoven Formation, Boncelles Sand.

\section{Introduction}

Marine sedimentation along the southern margin of the North Sea Basin is discontinuous, linked to the Savian Inversion Phase, across the Oligocene-Miocene series boundary (Vandenberghe et al., 2004; Gibbard \& Lewin, 2016; Vandenberghe, 2017). The corresponding sedimentary deposits in Belgium which are generally consisting of glauconitic sand are separated by a hiatus spanning the Oligocene-Miocene boundary. However, from a hydrostratigraphic perspective, late Oligocene sand has traditionally been included in the thick sequence of Neogene sand in the Campine (Coetsiers et al., 2014). This means that the Paleogene-Neogene transition is poorly known in Belgium. The strata deposited in the interval between the Rupelian and Burdigalian are not exposed. Few boreholes have traversed these strata, which have no economic interest. Each study focusing on the Paleogene-Neogene transition raises new questions about the connection between the bio- and lithostratigraphic framework. Therefore, the present review intends to present a coherent model for the stratigraphic transition from the Oligocene to the Miocene in Belgium, based on existing data scattered in literature. Data include literature data, new borehole geophysical data and in particular a discussion of the Molenbeersel borehole in the Belgian part of the Roer Valley Graben (RVG) (Deckers, 2016; Deckers \& Munsterman, 2020).

Such a review is timely in the light of the changes in lithostratigraphic nomenclature in the Netherlands involving nomenclature that has been in use for decades in Belgium (Wong et al., 2007; Munsterman et al., 2019). Also the chronostratigraphic age of lithostratigraphic units traditionally attributed to the Chattian in Belgium (Van Simaeys, 2004a; Van Simaeys et al., 2005) have been questioned and a more general presence of Aquitanian has been suggested not only in the RVG but also in the Antwerp Campine (Munsterman \& Deckers, 2020, this volume).

Notwithstanding recent findings of a more complete and complex stratigraphic succession across the Oligocene-Miocene boundary the general observation is that the Oligocene-Miocene hiatus increases towards the south and west, wedging out the Chattian strata and leaving them concealed under the Miocene cover (De Man et al., 2010). The base of the first Miocene lithostratigraphic unit, the Berchem Formation in the Antwerp Campine and the Bolderberg Formation in the eastern Campine, is of early Burdigalian age (Louwye et al., 2015; Deckers \& Louwye, 2019; Louwye et al., 2020, this volume).

Even the Rupelian (Lower Oligocene) becomes strongly eroded in direction of its type area near Antwerp, which was mostly realised already before deposition of Chattian sediments and resulting from the relative tilting of the Campine with subsidence to the northeast in direction of the RVG and erosion to the south and southwest in direction of the Brabant Massif (De Man et al., 2010; Vandenberghe, 2015). The RVG became strongly reactivated at the start of the Chattian and formed a sediment sink trapping up to $400 \mathrm{~m}$ of Chattian sediments (Hager et al., 1998; Van Simaeys, 2004a), compared to tens of metres of sediment thickness in the Campine and only residual deposits in the Antwerp area (Vandenberghe, 2017; Fig. 1).

Despite indications for being affected by the same tectonic pulses, sedimentation inside the subsiding RVG in NE Belgium and adjacent part of the SE Netherlands remained more continuous during the Upper Oligocene and crosses the Oligocene-Miocene boundary (Munsterman et al., 2019). Hence, a better understanding of the depositional system, active during the Paleogene-Neogene transition in Belgium, must focus on the nature and characteristics of the deposits unconformably underlying the earliest, clearly Miocene formations. However, the sedimentary succession, starting during the Chattian and possibly continuing during the Aquitanian and lower Burdigalian, is insufficiently characterised compared to the well-dated underlying Rupelian and overlying Burdigalian strata. The rather limited data have few biostratigraphical and hardly any sedimentological constraints, which hampers lateral correlations with the depositional systems of the RVG and Lower Rhine Graben in adjacent territories.

Recognising the Paleogene-Neogene transition and defining

https://doi.org/10.20341/gb.2020.009 


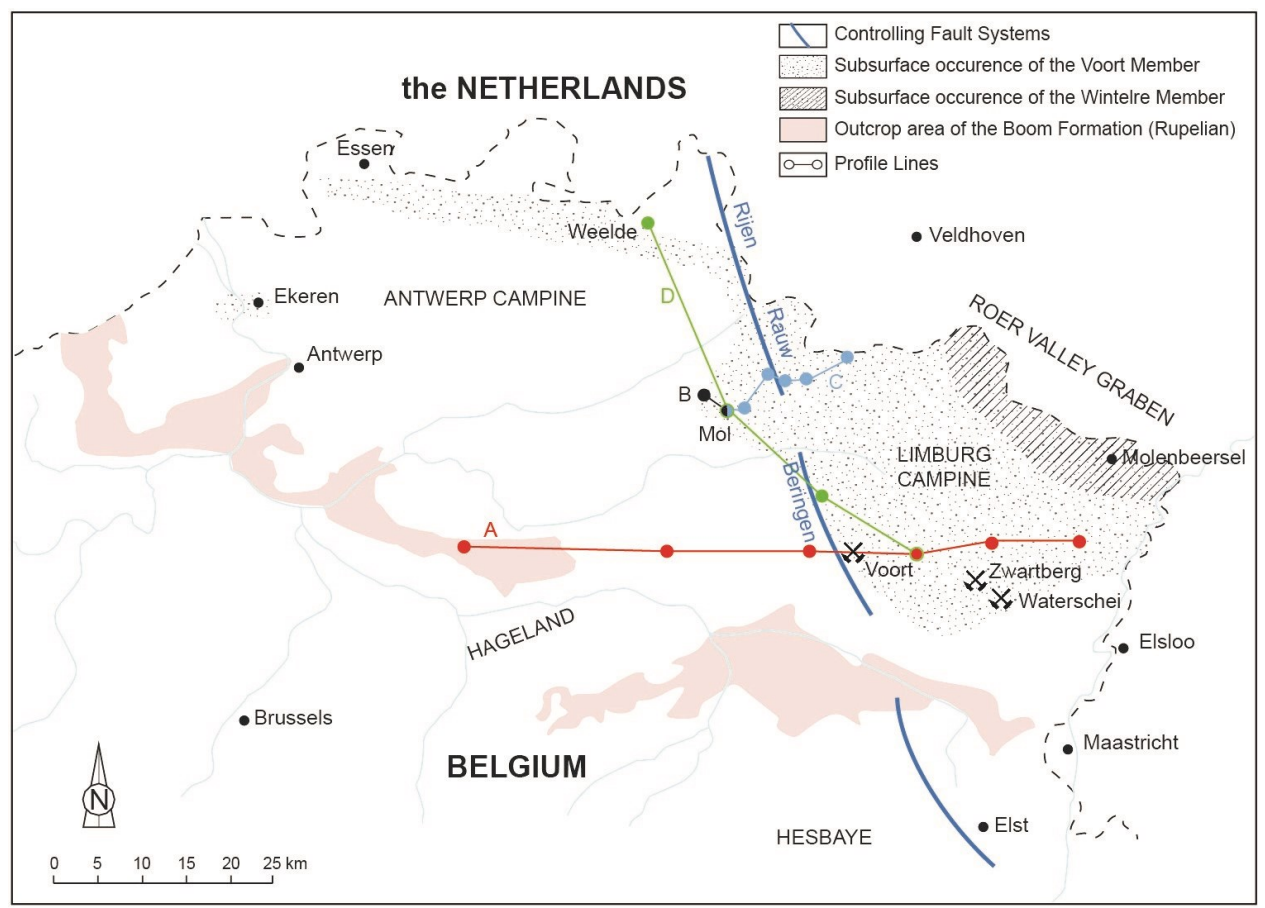

Figure 1. Location map of Rupelian and Chattian deposits in NE Belgium (after Vandenberghe, 2015, 2017), with major faults controlling preservation of the Chattian sediments. More Chattian deposits have been confirmed in the area north of Antwerp (Van Simaeys, 2004a). Profile lines A: Fig. 3; B: Fig. 6; C: Fig. 4; D: Fig. 10.

the sedimentary base of the Neogene succession in Belgium essentially resumes to properly define the Chattian deposits as they are currently known in Belgium, before attempting a correlation with the type Chattian in Germany and finally to bring Belgian and Dutch stratigraphic nomenclature to a common standard.

\section{Discovery of the Chattian in Belgium, establishing the Voort Formation in the Campine Basin}

In the rather monotonous succession of glauconitic sand of NE Belgium, Chattian sand was identified by its fossil content, initially molluscs, later on confirmed by micropalaeontology. Meanwhile, geophysical well log correlation and seismic stratigraphy are used to extend the biostratigraphic data for mapping purposes in northern Belgium. Initial recognition of Chattian sediments depended on exploration drilling, because these sediments do not crop out in their type area, as they are covered by overlapping Neogene Formations.

Original descriptions in the Archives of the Geological Survey of Belgium, e.g. by Stainier \& Schmitz on coal exploration borehole KB 79 (62W0205), drilled in 1909 at location of Voort I shaft of Zolder colliery, interpreted these strata in the interval between the 'Bolderien' (now recognised as Burdigalian) and Rupelian as Aquitanian. It is only after the identification of Chattian fossils (Schmitz \& Stainier, 1909; Stainier, 1911; Van Straelen, 1923) that a separate lithostratigraphical unit, namely the Voort Sand has been introduced with an assigned Chattian age.

A Chattian mollusc fauna was first observed in the old Molenbeersel borehole, drilled 1906-1907 for salt exploration (DOV kb18d49w-B205, GSB 049W0205; Stainier, 1911), and confirmed by Dr Wilhelm Wolff of the Königlich Preussischen Geologischen Landesanstalt (Schmitz \& Stainier, 1909). Subsequently a rich Chattian mollusc fauna was discovered in a series of coal exploration boreholes near Voort (Fig. 1). Molluscs were occurring in great abundance, often in monospecific layers of exceptionally large and thick-shelled species. They were found identical to the collections made in exploration boreholes and the Borth salt mine shaft of the Deutsche Solvay Werke in Rheinberg near Wesel in the Lower Rhine area (Nordrheinland-Westfalen), considered as the western type area for the Chattian in Germany. Moreover, this unit contained fossiliferous phosphatic nodules, identical to those found in the Elsloo Gravel, the base of the Miocene in the Limburg Campine (Schmitz \& Stainier, 1909).

A full appraisal of this fauna and its stratigraphical meaning was only possible by the sinking of the Voort shafts of Zolder colliery. The first description of the Voort Sand and its mollusc fauna is provided by Van Straelen (1923) in the Voort I shaft (DOV kb25d62w-B228, GSB 062W0226). In the upper part of this type section (-21 to $-31 \mathrm{~m}$ TAW; TAW: Belgian Ordnance Datum) the Voort Sand consists of dark green fine-grained glauconitic sand with fossiliferous phosphatic sandstone concretions. Above the weathered and decalcified top of this unit, lignite and phosphatic sandstone concretions were reworked in a gravel layer, correlated to the Elsloo Gravel, which marks the base of the overlying lower to middle Miocene Bolderberg Formation (Halet, 1920). The section below from $31 \mathrm{~m}$ to $-42 \mathrm{~m}$ TAW contains many shell beds and even coquinas, displaying a rich and well-preserved Chattian mollusc fauna (Fig. 2), listed by Van Straelen (1923, p. 63-64), which he considered fully comparable to the fauna recovered from the Chattian type area near Kassel (Germany). A taxonomic revision of the mollusc collection did not modify this interpretation (Ringelé, 1974). Later micropalaeontological research confirmed this age assignment (De Man et al., 2010). Between $-42 \mathrm{~m}$ and $-44 \mathrm{~m}$ TAW this unit is underlain by clayey sand, becoming sandy clay till $-52 \mathrm{~m}$ TAW, itself overlying stiff clay, respectively assigned to the Eigenbilzen and Boom Formations of Rupelian age. At the same time, molluscs disappear. The section from $-21 \mathrm{~m}$ to $-42 \mathrm{~m}$ TAW serves as the stratotype for the Voort Formation (Vandenberghe, 1988). However, this section is only representative for the basal part of the formation as this is more fully developed in the RVG (Geluk et al., 1994; NAM \& RGD, 1980; van Adrichem Boogaert \& Kouwe, 1997).

The more easterly located shafts of the Zwartberg and Waterschei collieries provided a somewhat different succession, the phosphatic concretions in the top of the formation being replaced by lignite intercalations and the mollusc fauna becoming less abundant and not so well preserved, but nevertheless presenting a similar assemblage (Van Straelen, 


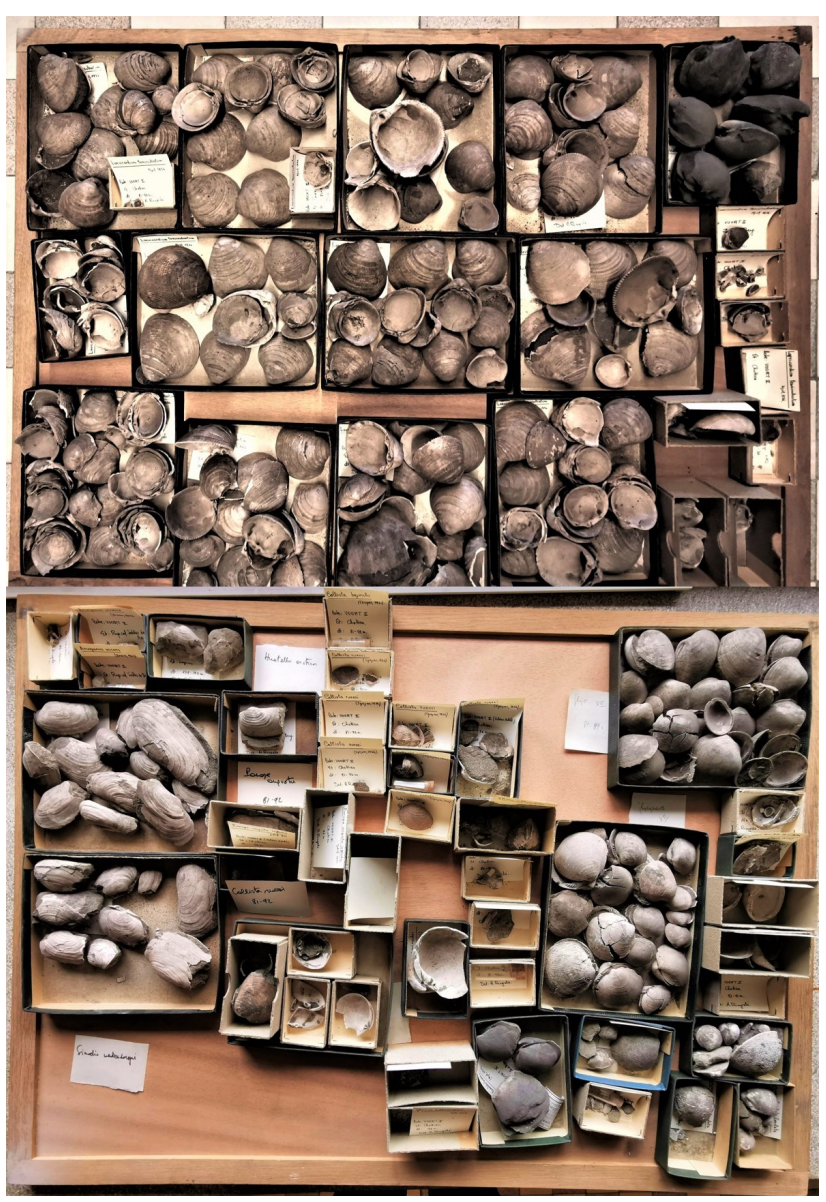

Figure 2. Part of the Chattian mollusc fauna collected in 1922 from shell beds in the depth interval 81-92 $\mathrm{m}(=-31$ to $-42 \mathrm{~m}$ TAW) in shaft Voort I (DOV kb25d62w-B228, GSB 62W226) of Zolder colliery, illustrating their abundance and preservation condition. Published by Van Straelen (1923), taxonomic review by Ringelé of KU Leuven (borehole sample library of Geological Survey of Belgium).

1923). A gravel layer, separating Chattian and Rupelian deposits rarely occurs in the Houthalen and Eisden coal mining shafts (Calembert \& Gulinck, 1954). However, the Elsloo Gravel at the base of the overlying Bolderberg Formation was used as a marker horizon and testifies of an important erosion phase and stratigraphic hiatus between Oligocene and Miocene sand (Van den Broeck, 1893; Halet, 1920). Subsequently the Chattian was recognised over a wider area in the Campine coalfield and the adjoining northeastern Campine, although the Chattian was not always individualised as a separate stratigraphic unit (Halet, 1936). Already before the era of geophysical and micropalaeontological reconnaissance the thickness of the Voort Sand on the Graben Shoulder could be quite correctly established at 20 to $48 \mathrm{~m}$ (in fact mounting to maximum $60 \mathrm{~m}$ ), and the complete formation in the Belgian part of the RVG was initially estimated at $180 \mathrm{~m}$ (Calembert \& Gulinck, 1954; Fig. 3).

Independently of the coal exploration, a remnant deposit of Chattian age, assigned to the Voort Formation, was discovered in the Antwerp harbour area. The Ekeren borehole (DOV GEO60/2718-A, GSB 15W0142), described by Gulinck (1960), displayed in the interval $31-40 \mathrm{~m}$ a greenish very fine micaceous calcareous glauconite-rich sand with shell layers and almost black glauconitic sand at the base, covered by dark green fine-grained glauconite-rich more clayey sand with gravel base, assigned to the Edegem Member of the Berchem Formation (Burdigalian), and overlying compact grey clays, assigned to the Boom Formation (Rupelian). Laga (1974, 1976) discovered
Protelphidium (Nonion) roemeri Cushman 1936 in this unit, proving its Chattian age, subsequently confirmed by dinocyst analysis by Van Simaeys (2004a, chapter 5; see Section 5.2.). So far, this remains a unique dated find in Antwerp harbour but this outlier certainly represents the westernmost extension of the Voort Formation subcrop mapped in northern Antwerp Campine (Essen borehole, DOV B/1-1092; GSB 001E0071) and further connected to the RVG in the area north of Mol (Fig. 1).

The transboundary (hydro)geological mapping project $\mathrm{H} 3 \mathrm{O}$ De Kempen (Vernes et al., 2018) allowed for a renewed appraisal of the lithological composition and thickness change of the Voort Formation. Interpreting and correlating all moderately deep wells in the border region and its transition to the RVG allowed to recognise a consistent positive gamma ray anomaly within the Voort Sand, serving as a marker bed, not to be confounded with the gamma ray peak at the base of the overlying Berchem Formation. This gamma ray increase is observed with a characteristic peak and at a rather constant distance from the base of the Voort Formation in the Campine west of the RVG (Fig. 4). More to the east on the Graben Shoulder (Meeuwen-Helchteren area, see Fig. 3), where the thickness is greater, the gamma ray increase is also quite clear but changes are more gradual. Even in the RVG this gamma ray increase is discernible, indicative for a regional consistent effect (see Section 5, Fig. 8).

\section{Outliers of Chattian sand in eastern Belgium and their relation to the Chattian of the Campine}

\subsection{Boncelles Sand}

Outside the Campine Basin, patchy sand and clay deposits discontinuously covering much older folded strata are widespread on the northern slope of the Ardennes and in Condroz / Entre-Sambre-et-Meuse regions in eastern Belgium. These deposits are either marine, fluvial or limnic, occurring in different sequences and are partly reworked (Leriche 1922; Fourmarier, 1934; Calembert \& Gulinck, 1954). The isolated sand deposits south of the Meuse River and covering the Ardennes / Hautes Fagnes are mostly considered as marine lower Oligocene and are in some instances covered with Miocene continental deposits (Demoulin, 1989). However south and east of Liège an about $10 \mathrm{~m}$ thick sand deposit, the Boncelles Sand, is rather well defined among these sedimentary units and extensively described by Ancion \& Van Leckwijck (1947). When not oxidised this fine sand contains a marine mollusc fauna, 'most likely of Chattian age', based on their similarity with the German Chattian (Rutot, 1907; Destinez, 1909). Ancion \& Van Leckwijck (1947) listed among other the Chattian guide fossil Meretrix (Cytherea) beyrichii.

In fact, upon closer scrutiny the Oligocene sand of the Ardennes may consist of two units: the Chattian Boncelles Sand overlying a presumably 'Tongrian' (Lower Oligocene) Sart Tilman Sand (Fourmarier, 1920). Coincidently, discovery of presumably Chattian deposits in the concealed Campine Basin and on outliers of unconsolidated sediments south of the Meuse River occurred in the same period.

As already suggested by Calembert \& Gulinck (1954, p. 507) Chattian sand can be expected to occur also in outliers north of the Meuse River, overlying the more ubiquitous sand assigned to the Sint-Huibrechts-Hern Formation, considered equivalent to the Sart Tilman Sand south of the Meuse River. The former Maurissen sand pit, located on top of the Cretaceous carbonates in the Hesbaye region between Tongeren and Maastricht, may be the northernmost occurrence of the Boncelles Sand (Fig. 5). Although on the geological map sheet 34 Tongeren, Claes et al. (2001) have mapped all near-surface oxidised non-fossiliferous very fine sand deposits as lower 


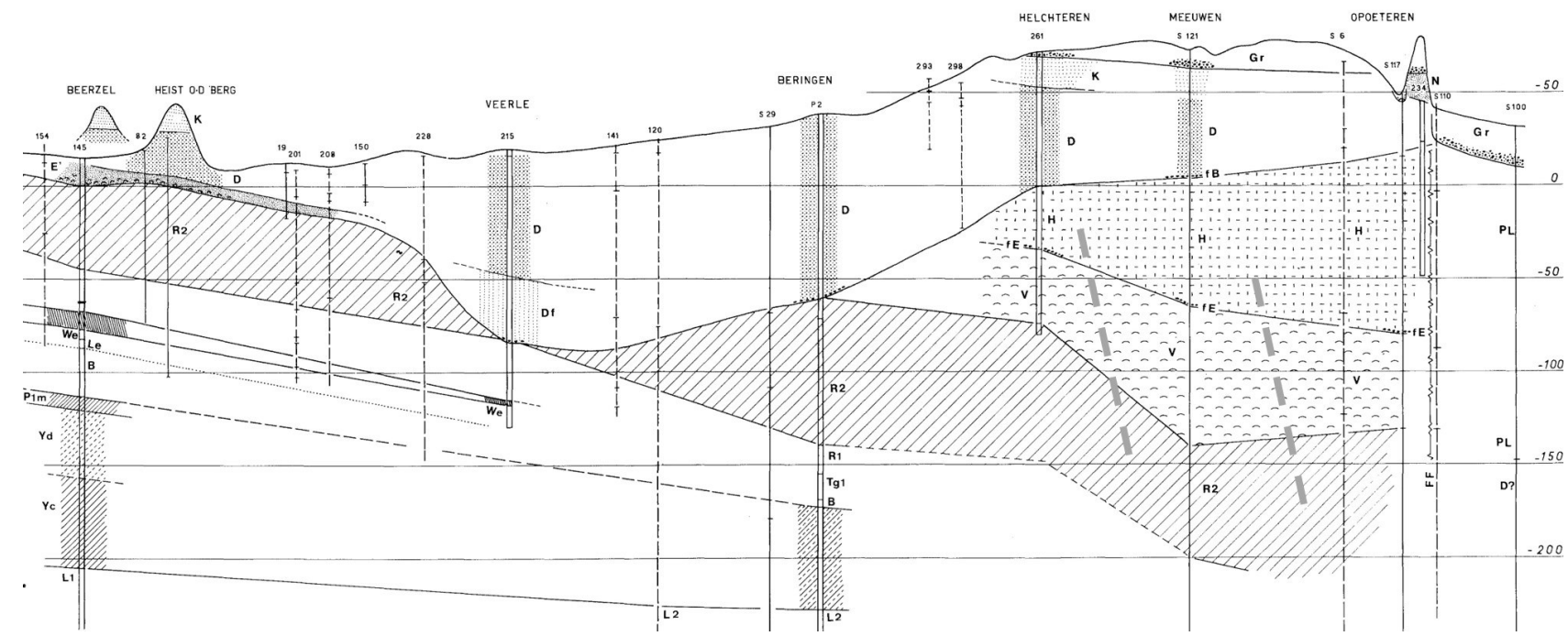

Figure 3. West-East geological profile Heist-op-den-Berg-Beringen-Neeroeteren in the Campine Basin through 'Diest channel' towards RVG showing position of Voort Sand (V), overlying Eigenbilzen-Boom Formations (R2), overlaid by the Bolderberg Formation (B) along the Elsloo Gravel (fE). The Voort Sand stepwise increases in depth and thickness between Helchteren and Opoeteren across the Louwel and Dorne faults (represented by dashed lines, after Rossa, 1986), whereas its western onlap along the outer Graben Shoulder Rijen-Rauw-Beringen fault systems (cf. Wong et al., 2007, p. 154) has been removed by erosion of the Diest channel (compilation by Marcel Gulinck in 1973, modified after Geological Survey of Belgium archive MG/73/339). Location: profile A on Fig. 1.

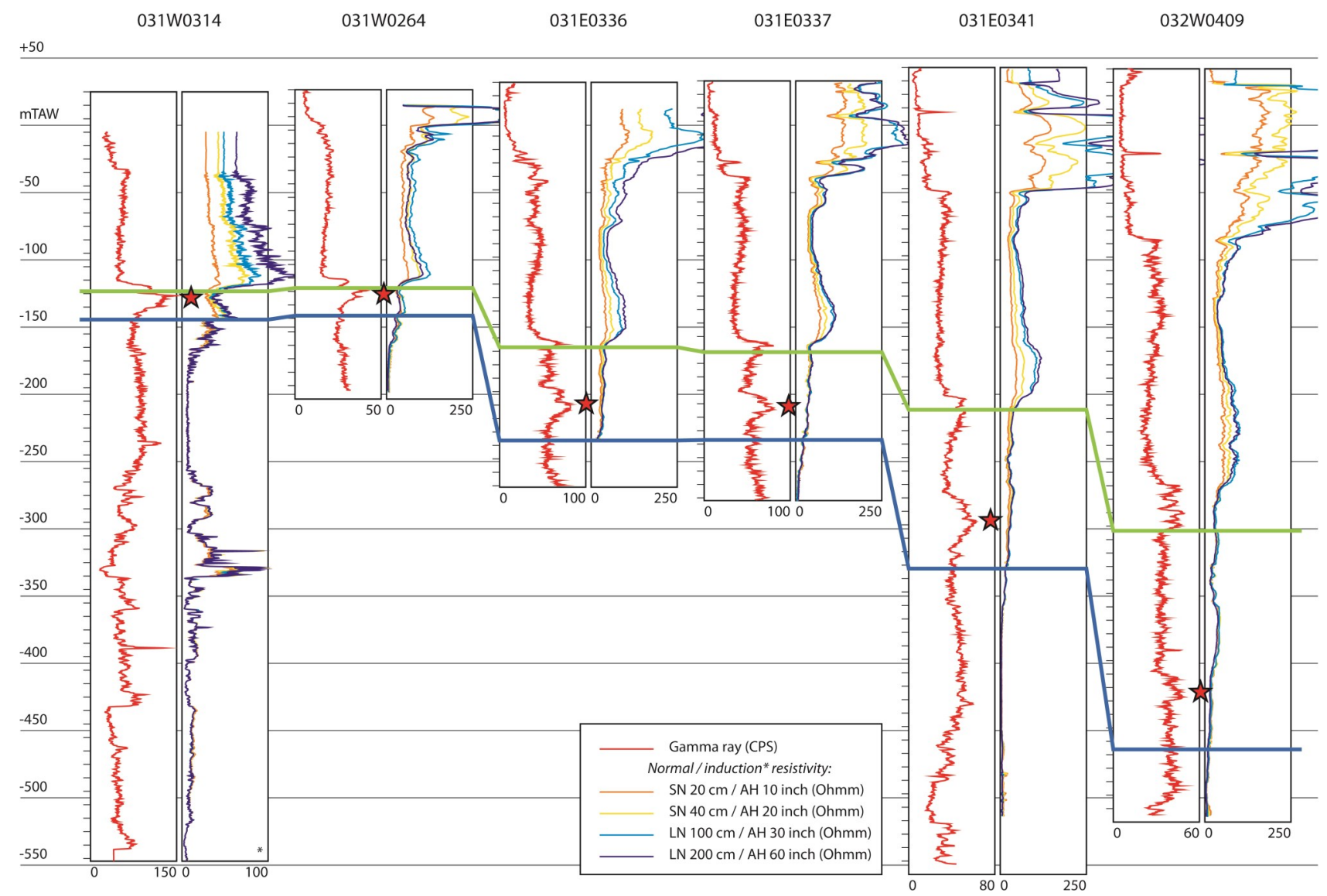

Figure 4. WSW-ENE profile in the area of Mol-Dessel-Lommel, gamma ray and resistivity logs displayed, showing the upper and lower boundary of the Voort / Veldhoven Formation, respectively green and blue lines. A thickness increase is noticeable from west to east, across the graben boundary faults (marked by jumps in depth). A gamma ray peak within the Voort/Veldhoven Formation serves as a marker horizon (marked by a red star). With increasing thickness, this zone with elevated gamma ray value moves from top to middle of the formation, indicating that the thickness increase is mostly due to the formation becoming more complete by adding younger strata, which may be reduced to a condensed section in the west, however (cf. Section 5). Note that the potential equivalent of the Edegem Member of the overlying Berchem Formation may be included in the top of the Voort/Veldhoven Formation. Profile modified from H3O De Kempen project (Vernes et al., 2018). Location: profile C on Fig. 1. 


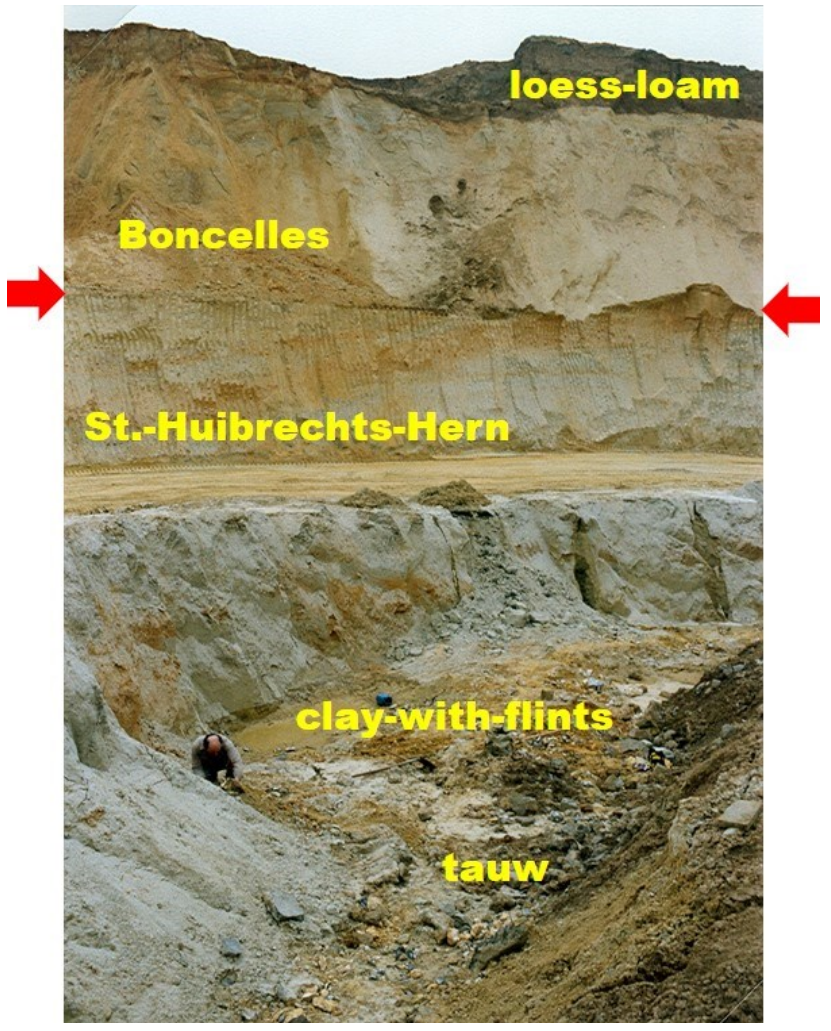

Figure 5. Former Maurissen sand pit located in Millen-Elst in the Hesbaye region (DOV BGD107W0304). Location see Fig. 1. Below a displaced dark brown remnant of the loam-loess cover, a yellowishoxidized fine-grained to silty sand is tentatively correlated to the Boncelles Sand. This unit is overlying, with a sharp curved contact visible in the lower half of the upper exploitation level (and indicated by arrows), a clean whitish sand assigned to the Sint-Huibrechts-Hern Formation, itself covering a clay-with-flints and silicified limestone ('tauw') deposit at the bottom of the pit (photo Edwin Defour, Werkgroep Krijt en Vuursteeneluvium, 1991).
Oligocene Sint-Huibrechts-Hern Formation, the section in the Maurissen pit shown in Figure 5 allows clearly to distinguish two separate units, similar to the situation on the Boncelles plateau south of Liège. It is suggested that the lower unit indeed corresponds to the lower Oligocene Sint-Huibrechts-Hern Formation but the upper unit could very well be correlated with the Boncelles Sand. Based on these considerations the occurrences of the Boncelles Sand can be considered as outliers of the contiguous Voort Sand in the Campine further north. This tentative interpretation implies the absence of the Rupelian Boom Clay Formation in the area.

\subsection{Chattian architecture in the Campine}

The occurrence of the Boncelles Sand seems to coincide with the area influenced by the subsiding RVG. This subsiding area is delineated in the west by the the Rijen-Rauw and Beringen fault systems and their southern prolongation which approximately coincides on Figure 1 with the western boundary of the Eigenbilzen Formation. Approaching this fault at MolRauw the base of the thin Voort Formation in the Campine is marked by a slight angular unconformity with the underlying Rupelian strata as recognised on seismic sections (Lie, 1983 in the coal exploration surveys Neeroeteren-Rotem 1980 and Meeuwen-Bree 1981; Demyttenaere, 1989 in the graben reconnaissance campaign Poppel-Lommel-Maaseik 1984; SAFIR report by Cornélis et al., 2001, further elaborated in Wouters et al., in prep., in the NIRAS/ONDRAF campaign in Mol-Dessel 1996; Fig. 6). The main body of the Voort Formation is deposited east of this external RVG fault system and its thickness increases considerably towards the central part of the graben as explained already by earlier authors (see Section 2) and presented on Figure 3 (see also Matthijs, 1999 or Buffel et al., 2001). This change in structural grain was already described by Stainier (1929, p. 185-186) who noticed a marked transgression of the Chattian sea towards the southeast of Belgium, suggesting graben tilting and implicating the start of emersion in the west.

Apparently, graben tectonics provided new accommodation space and preservation potential for the Chattian deposits in the east of Belgium (Fig. 7). To the west of the external RVG boundary faults in the northern Antwerp Campine down to Antwerp harbour the Voort Formation thins and is only patchily preserved (Fig. 1). Moreover these Chattian sediments may give way to Aquitanian and lower Burdigalian sand before being

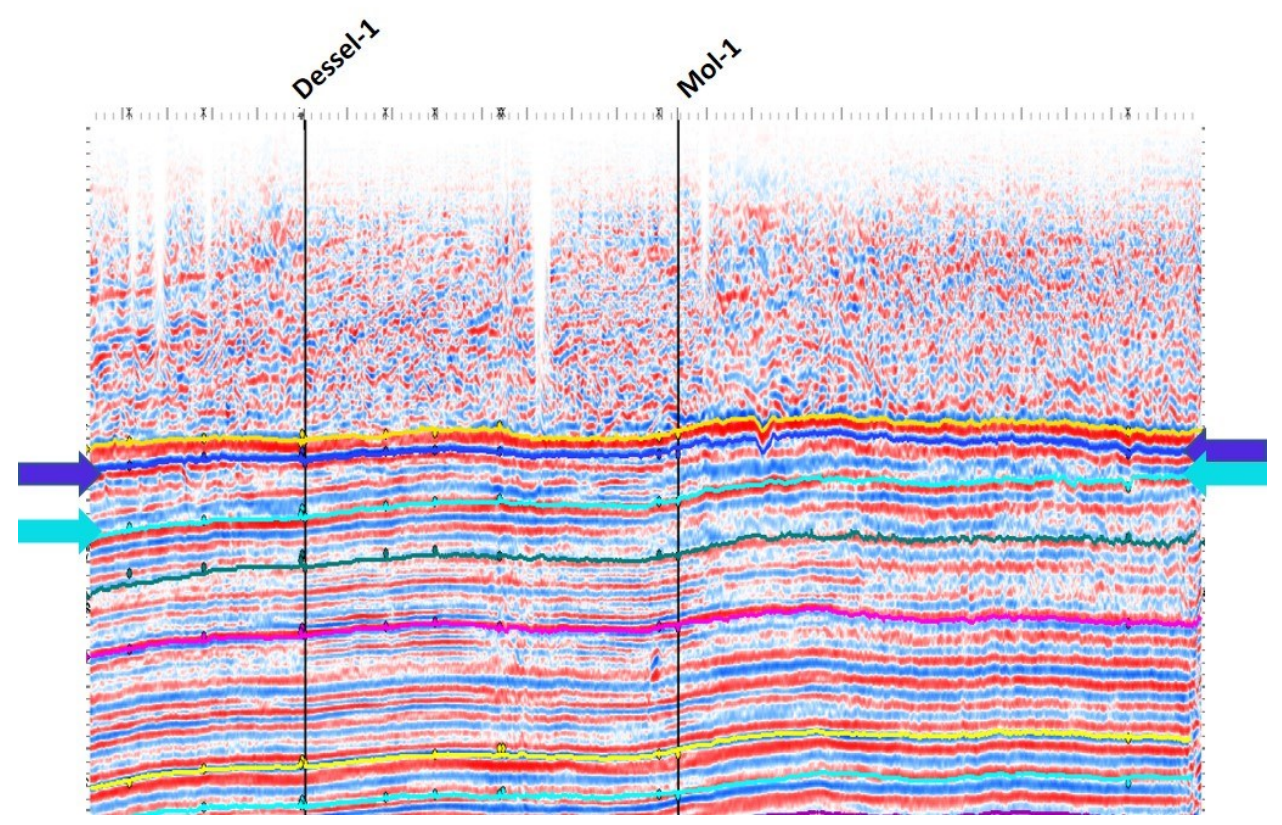

Figure 6. Seismic section 96ON-01, located between $\mathrm{Mol}$ (South) and Dessel (North) crossing wells Dessel-1 (DOV ON-Dessel-1; GSB 31W0300) and Mol-1 (DOV ON-Mol-1, GSB 031W0314), showing interval 0$280 \mathrm{~ms}$ TWT (Two Way Time). The Voort Formation (between light blue and dark blue reflectors) markedly increases in thickness towards the graben and gradually wedges out towards the south. Reprinted with permission from Wouters et al., in prep. Location: profile B on Fig. 1. 


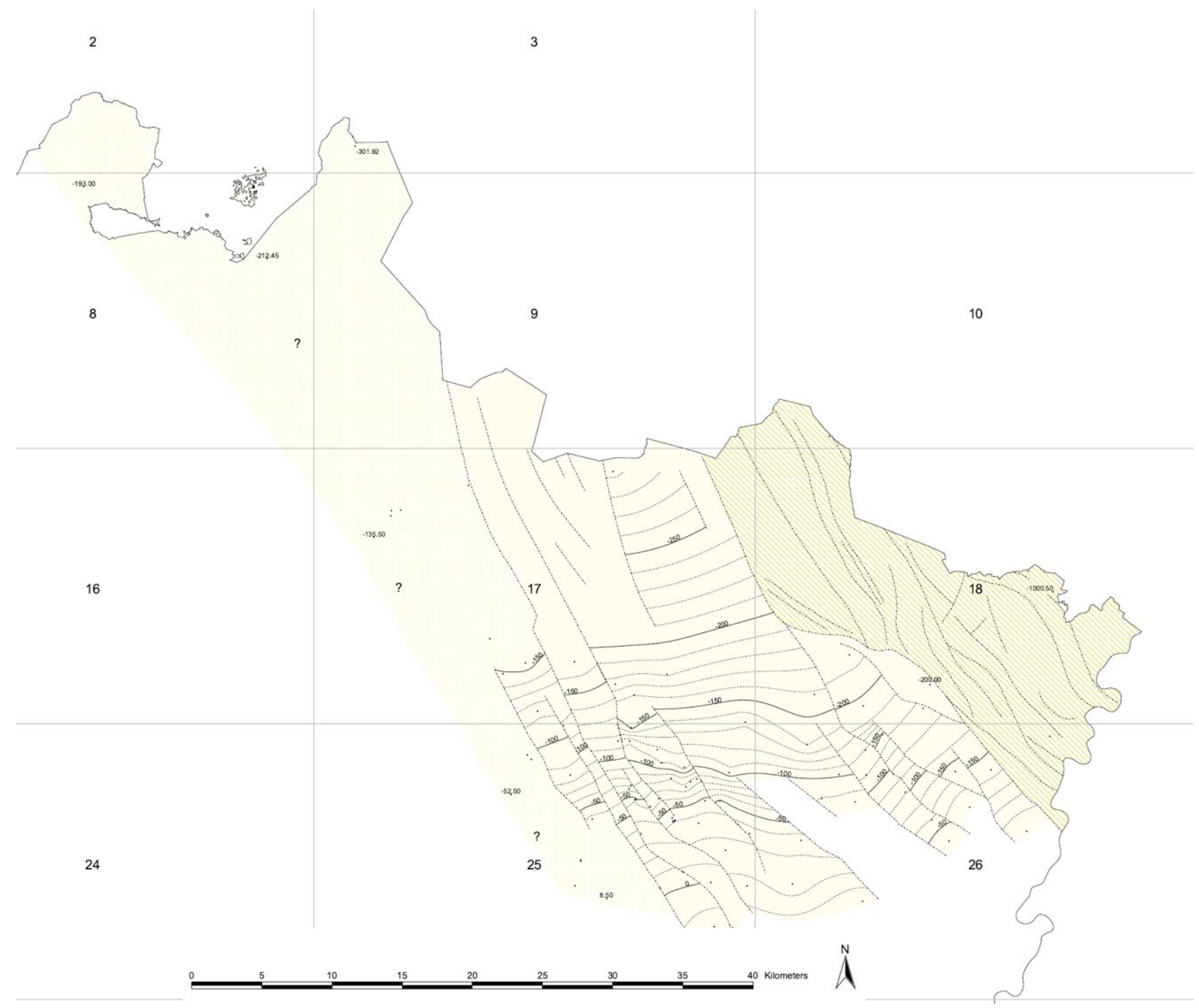

Figure 7. Isohypse map of the Voort Formation (Vancampenhout, 2004; fault pattern after Matthijs, 1999 and Buffel et al., 2001). No isohypse could be drawn in the Antwerp Campine where the formation is thin and its boundary with the overlying formation contested. For RVG we refer to Broothaers et al. (2012) and Deckers (2016) for seismostratigraphic interpretation.

covered by the Berchem Formation sensu stricto, deposited during the Burdigalian after the Early Miocene Unconformity (EMU; see Louwye et al., 2020, this volume). The consequence is that no geological subcrop map exists covering the entire Voort Formation. Although this was attempted in a previous geological 3D model of Flanders (G3Dv2, Broothaers et al., 2012) the stratigraphic succession scheme was refuted, leading to a revision of the 3D model. The recent geological 3D model of Flanders (G3Dv3) combines the Chattian sand with the sand deposited on top of the EMU in a combined Complex of late Oligocene to Middle Miocene Sand (Deckers et al., 2019). This geological 3D model of Flanders maps Voort Sand only in between the external graben boundary fault and the central RVG; because of insufficient borehole control no mapping is provided for the RVG where the stratigraphic succession is more complete and the Dutch subdivision prevails.

\section{The Oligocene-Miocene transition in the RVG and connection to the Dutch stratigraphy}

In the Dutch stratigraphic nomenclature the regional uplift and subsequent unconformity induced by the late Savian tectonic phase serves as the boundary between the Middle and Upper North Sea Groups of the Cenozoic North Sea Supergroup (Letsch \& Sissingh, 1983; Wong et al., 2007). This boundary slightly succeeds the Paleogene-Neogene boundary as Aquitanian sediments are encompassed in the Middle North Sea Group. The more pronounced Mid Miocene Unconformity (MMU) attributed to the Serravallian postdates the Savian EMU unconformity and may obscure its recognition.

The final deposits of the Middle North Sea Group are most typically represented in the RVG and assigned to the Veldhoven Formation, itself further subdivided into a threefold succession, starting with the predominantly sandy Voort Member, overlain by the predominantly clayey Veldhoven Member, overlain by the again predominantly sandy Someren Member. The Veldhoven Clay Member was the first to be distinguished (van Adrichem Boogaert \& Kouwe, 1997), lending its name to the Veldhoven Formation. For facilitating the distinction between formation and member name, the Wintelre Member was proposed by Weerts et al. (2003).

A revised bio- and lithostratigraphical interpretation of the Miocene over different structural domains, from Campine over RVG to Venlo Block in the southern Netherlands, is provided by Munsterman et al. (2019) who subdivided the Breda Formation and constrained its dinocyst biozonation, allowing for a potential better alignment of Dutch and Belgian MioPliocene stratigraphy. This has also consequences for the underlying Veldhoven Formation: all Miocene deposits below 
the EMU, i.e. Aquitanian up to the middle Burdigalian, are assigned to the Veldhoven Formation, those above are assigned to the new Groote Heide Formation, which is correlated to the Berchem Formation. This scheme fits with the eastern Campine succession, considering the Houthalen and Genk Members of the Bolderberg Formation equivalent to the Kakert and Vrijherenberg Members of the new Groote Heide Formation (Deckers \& Louwye, 2019). It should be noted however, that the Berchem Formation falls in between the Savian Unconformity and MMU and that the age ranges of these unconformities must be constrained by the ages of all underlying and overlying sediments (cf. fig. 8 in Munsterman et al., 2019).

As discussed above, the Voort Formation as defined in the Belgian coal mining district forms the lower part of a much thicker sequence fully developed in the RVG, which resumed strong tectonic subsidence starting with the Chattian (Geluk et al., 1994; Deckers, 2016). This resulted in a more complete deposit than in the Campine area outside the RVG influence. This thick deposit assigned to the Veldhoven Formation (de Lang, 2003) extends across the boundary into the Netherlands where more extensive data are available about this stratigraphic interval (TNO-GSN, 2018a).

In the early practice of describing and interpreting boreholes north of the Campine coalfield and in the north of the Antwerp Campine in Belgium, the clayey intercalation near the top of the Voort Formation section, described in Section 2 and figured in Figure 4, was distinguished and considered as Veldhoven Clay, inspired by the occurrence of such a clay layer above Voort Formation type sand in the Veldhoven-01 borehole (B51D0127) in the Netherlands close to the Belgian-Dutch border. This practice was formalised in the Belgian stratigraphic subdivision by Vandenberghe (1988, p. 206-207) and Laga et al. (2001); this Veldhoven Clay was considered as a member within the Voort Formation and because of lack of good stratigraphic data on this clay interval in Belgium the Dutch Veldhoven-01 borehole was designated as the stratotype reference.

However, two complications have arisen since. The first complication is that this clay layer in the Veldhoven-01 borehole has its name changed from Veldhoven Member before to Wintelre Member now (TNO-GSN, 2020). More important is the second complication, namely that extensive geophysical well $\log$ correlations during the recent transboundary $\mathrm{H} 3 \mathrm{O}$ project (Vernes et al., 2018) demonstrated that the clayey interval as shown in Figure 4 does not correspond to the thicker Wintelre, formerly Veldhoven Member in the Veldhoven-01 and other Dutch boreholes. It is nowadays well established that the subcrop of the Wintelre Member is restricted to the RVG north of the Feldbiss-Grote Brogel boundary fault system (Deckers et al., 2019). Therefore the high-GR (natural gamma ray borehole $\log$ ) signature pointing to a clayey interval in Figure 4, formerly also described as Veldhoven Member in Belgian stratigraphy - what contributed to much confusion about the extension of this member-must be another unit occurring below the Wintelre Member, hence part of the Voort Member.

The Wintelre Member in the Dutch stratigraphy is the middle unit of a threefold subdivision of a formation that inherited the name Veldhoven, still with the Veldhoven-01 borehole as reference section; below the Wintelre Member occurs the Voort Member and above occurs the Someren Member (TNO-GSN, 2018b).

The available palynological data showed the Voort Formation to be Chattian according to its original definition in the Belgian Campine-hence also the Voort Member of the Veldhoven Formation - whilst the ages of the Wintelre and Someren Members remained uncertain but probably latest Chattian to Aquitanian (van Adrichem Boogaert \& Kouwe,
1997; Van Simaeys et al., 2005).

The Molenbeersel well, drilled in 1988 by the Geological Survey of Belgium (DOV kb18d49w-B226, GSB 049W0226), is the only borehole reaching deep enough to cross the Oligocene-Miocene transition interval in the Belgian part of the RVG (Fig. 8). Poor lithological documentation and the absence of a reference geophysical log stratigraphy have hindered a consistent interpretation. In particular solid criteria to identify even existing regional lithostratigraphic units or to define their boundaries are lacking. This lack of rigorous criteria defining lithostratigraphic units hinders also the full understanding of the meaning of biostratigraphic analyses for the palaeogeographical evolution of the area. Moreover, the stratigraphical framework initially applied did not yet recognise the existence of the Someren Member. This has led to a suite of different stratigraphic interpretations of the Molenbeersel borehole ever since it was drilled (Demyttenaere \& Laga, 1988; Hager et al., 1998; Verbeek et al., 2002; Broothaers et al., 2012; Deckers, 2016).

Verbeek et al. (2002), followed by Wong et al. (2007, figs 7 , 8), have also interpreted the Molenbeersel borehole along a NW -SE geophysical log correlation profile, mainly in the Netherlands in terms of seismostratigraphic units. However, their unit V includes the Eigenbilzen Formation of Rupelian age together with the Voort and Wintelre Members of the Veldhoven Formation. The boundary with the overlying unit VI, originally considered as the lower part of the Miocene Breda Formation but now correlated to the Someren Member of the Veldhoven Formation, is situated at about $770 \mathrm{~m}$, well below the depth assumed for the Oligocene-Miocene by Hager et al. (1998) but almost coinciding with the top of the Veldhoven Clay Member (old terminology) in Demyttenaere \& Laga (1988). It looks as if Hager et al. (1998, fig. 4) include in the Chattian a sandy interval of about $100 \mathrm{~m}$ thickness above a manifest clay layer identified in the GR log of the Molenbeersel borehole that Demyttenaere \& Laga (1988) and Verbeek et al. (2002) consider as the top of the Chattian, i.e. extending the Veldhoven Formation upwards to include the Someren Member. Matching the Veldhoven Formation to the Chattian has inadvertently led to raise the Oligocene-Miocene boundary towards levels without direct biostratigraphic control to support this assumption.

In agreement with the lithostratigraphic correlation scheme established for H3O Roerdalslenk project (Deckers et al., 2014, after Broothaers et al., 2012 and Matthijs et al., 2016) Deckers (2016) has reviewed the interpretation of the Chattian in the Molenbeersel borehole based on borehole geophysics (Vertical Seismic Profiling, geophysical logs and synthetic seismogram) coupled with the interpretation of $174 \mathrm{~km} 2 \mathrm{D}$ seismic lines (shot or reprocessed in 2007-2008) in the Belgian RVG, including the Molenbeersel borehole site. Deckers (2016) could demonstrate the presence of the threefold subdivision established by van Adrichem-Boogaert \& Kouwe (1997) discussed above in the Molenbeersel borehole, practically in the same interval as interpreted as Chattian by Hager et al. (1998), as well as its regional consistency in the Belgian part of the RVG. The total thickness of the Chattian estimated in the Molenbeersel borehole is $295 \mathrm{~m}$ (between 680 and $975 \mathrm{~m}$ ), compared to 243 $\mathrm{m}$ (between 860 and $1103 \mathrm{~m}$ ) in the reference Veldhoven-01 borehole (https://www.dinoloket.nl/sites/default/files/file/ DRW_2140.pdf).

The resulting subdivision of the Veldhoven Formation in the Molenbeersel borehole (Fig. 8) is as follows: the sandy Voort Member at the base between 840 and $975 \mathrm{~m}$, the middle clayey Wintelre (ex-Veldhoven) Member between 774 and $840 \mathrm{~m}$ and the upper Someren Member between 680 and $774 \mathrm{~m}$ ). The differences with the relative thicknesses of the three Members in 


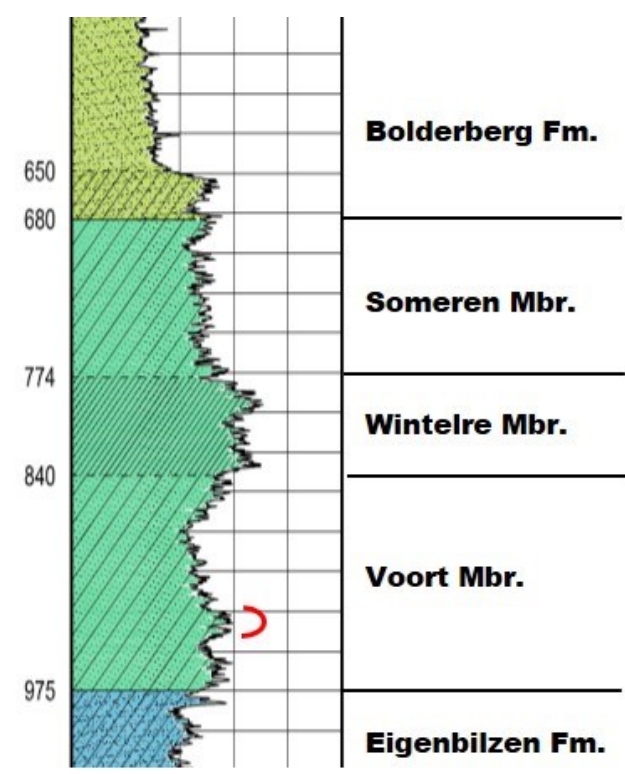

Figure 8. Lithostratigraphic gamma ray interpretation of borehole Molenbeersel (DOV kb18d49w-B226, GSB 049W0226), reference log for the Belgian part of the RVG, displaying threefold subdivision of the Voort Formation, now considered synonymous to the Veldhoven Formation established in the Netherlands, from top to bottom the Someren, Wintelre (ex-Veldhoven) and Voort Members. Notice the increase in gamma ray readings over a $20 \mathrm{~m}$ interval $(920-940 \mathrm{~m})$ in the lower half of the Voort Member (indicated by red half-circle), corresponding to the intra-Voort Member marker horizon in the adjoining Campine Basin (cf. Fig. 4) (modified after Broothaers et al., 2012).

the Veldhoven-01 borehole are for a large part due to the precise picking criteria of the boundaries of the middle clayey Wintelre Member because of the different log types and quality available and the gradual lithological change at both its lower and upper boundary. Note also on Figure 8 that within the Voort Member at about 920-940 $\mathrm{m}$ occurs a conspicuous increased GR excursion comparable to the GR excursion in Figure 4 and erroneously interpreted as the Wintelre (ex-Veldhoven) clay in the past in other boreholes (see Section 2).

The current subdivision is mainly based on geophysical well $\log$ correlations but lacks biostratigraphical control and is therefore prone to further revision. Especially the Someren Sand Member and its contact with the Houthalen Member of the overlying Bolderberg Formation remains poorly characterised. However, by geophysical well log correlation it coincides with the recently established boundary between the Veldhoven and Groote Heide (ex-base Breda) Formations in the Dutch type section of Groote Heide borehole (Munsterman et al., 2019). The Molenbeersel borehole is outstanding among the boreholes having traversed the complete Veldhoven Formation in the RVG by its gamma ray log allowing a rather obvious threefold subdivision of the Veldhoven Formation (Fig. 8). Such subdivision is more complex in other boreholes with rather random boundary picking as a consequence. This is possibly related to the interfingering and boundary diachronism of the Wintelre and Someren Members as shown in the stratigraphic scheme in Wong et al. (2007, fig. 9). Hence, the exact position of the Paleogene-Neogene boundary defined in a restricted number of boreholes by Munsterman et al. (2019) cannot be reliably pinpointed in other boreholes.

The transition between the Someren Member and the Miocene Groote Heide (ex-Breda) Formation in the Dutch RVG is defined by a slight unconformity and the sediments below the unconformity are consistently already middle Burdigalian in the interpretation of Munsterman et al. (2019). On the Campine Block and along the western flank of the RVG, a sharp GR increase, associated with the deposition of black glauconitic sand of the Berchem Formation in Belgium, is marking this unconformity (cf. the gamma ray peak overlying the top of the Voort Formation on Fig. 4). This interpretation shows that the fully developed Veldhoven Formation reaches well above the end of the Chattian. This associated increased GR on the Molenbeersel borehole $\log$ is at $680 \mathrm{~m}$ where it is considered as the base of the Bolderberg Formation (Fig. 8).

\section{Comparison with the Chattian in the Lower Rhine Embayment and chronostratigraphic control of the Chattian in Belgium}

\subsection{The Molenbeersel borehole in the RVG}

Originally, the Paleogene-Neogene boundary was defined on the basis of changes in mollusc faunas and different distribution of strata across Europe (Hörnes, 1853), as were also the Chattian (Fuchs, 1894) and Aquitanian (Mayer-Eymar, 1858) stages. In Europe, correlations in the Chattian used the molluscbased twofold Eochatt-Neochatt division (Hinsch, 1956) and later the also mollusc-based Chatt $\mathrm{A}, \mathrm{B}$ and $\mathrm{C}$ subdivision proposed by Anderson (1961) and Anderson et al. (1971). Graben subsidence provided a link between the Belgian deposits and the time- and facies-equivalent Kölner Schichten (Formation) of the Lower Rhine Graben (Demoulin, 1989).

The Veldhoven Formation in the Molenbeersel borehole was incorporated in a regional Chattian correlation study in the Lower Rhine district and its border area by Hager et al. (1998). Based on numerous geophysical log correlations these authors identified four continental clay-with-lignite intercalations in the fine-grained marine glauconitic sand invading the Lower Rhine Embayment during the Chattian; the Schneider \& Thiele (1965) hydrostratigraphic codes could be applied to the clay and sand alternations.

The same codes are also presented in the classical stratigraphic scheme of the Cenozoic Lower Rhine Basin in Germany by Schäfer \& Utescher (2014, fig. 3) displaying similar lithological alternations from the Chattian Grafenberg and Köln Formations to the Miocene Ville Formation. The relationship between the Chatt A, B, C subdivisions and the Schneider \& Thiele codes (S\&T) was determined in the Schacht 8 section of Rheinpreussen colliery near Moers in the Lower Rhine area (Hager et al., 1998 fig. 5).

Although in the Molenbeersel borehole not all Chattian S\&T units could be recognised individually and some had to be grouped, Hager et al. (1998, figs 4, 5; Fig. 9) proposed a S\&T subdivision in the borehole, calibrated to the mollusc zonation in Schacht 8, that logically fits the lithostratigraphic subdivisions discussed in Section 4 (Fig. 8; Table 1).

Apparently the clayey marker around $920-940 \mathrm{~m}$ in Molenbeersel borehole, and hence the corresponding clayey marker in the Voort Member of the Campine (red star in Fig. 4), is identified as S\&T 06. Because the succession of S\&T horizons apparently can be followed across the different tectonic blocks in the studied area Hager et al. (1988) suggest the S\&T lithological variations could be eustatic.

Also note that the top sand unit with code 4 interpreted by Hager et al. (1988) as Chattian is already considered Aquitanian by Schäfer \& Utescher (2014, fig. 3), contributing to the uncertainty of the stratigraphic age of the top of the Veldhoven Formation in the RVG, further corroborated by Munsterman et al. (2019).

\subsection{The Campine Block west of the RVG}

No dinoflagellate cysts were studied in the Molenbeersel well 


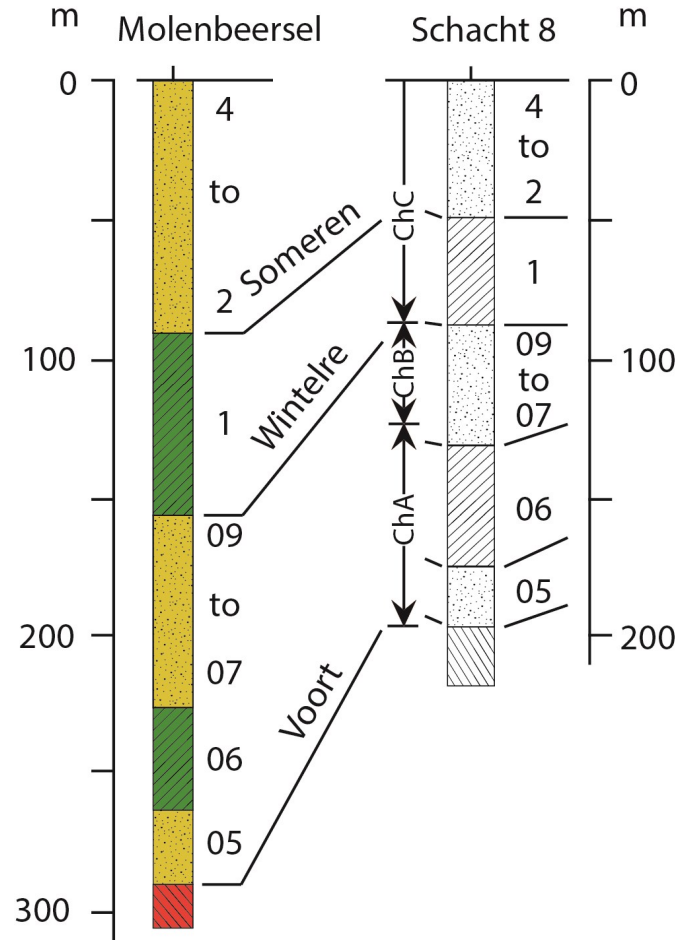

Figure 9. Correlation of the Molenbeersel borehole with the Chattian reference section Schacht 8 of Rheinpreussen colliery near Moers (Lower Rhine area), showing the Chattian subdivision A, B, C of Anderson (1961) and Anderson et al. (1971) and with the Schneider \& Thiele (1965) hydrostratigraphic codes against the current lithostratigraphic subdivision of the Veldhoven Formation; top Veldhoven Formation and/or end Chattian flattened (extracted from Hager et al., 1998, figs 4 and 5).

but extensive dinocyst biostratigraphic analysis was applied and a zonation for the southern North Sea was established based on a series of boreholes and shafts in the Belgian Campine, extended into the Netherlands and northern Germany (Van Simaeys, 2004a, b; Van Simaeys et al., 2005). These authors distinguished three North Sea Oligocene (NSO) dinocyst zones in the Chattian.

In the Veldhoven Formation of the Weelde borehole (DOV kb8d8e-B161; GSB008E0159), three sedimentary sequences were distinguished separated by two thin intraformational gravel layers, which seem to coincide with boundaries of the three Chattian NSO dinocyst zonations (Fig. 10). The boundary gravel between the lower and middle sedimentary sequence corresponds to the southern North Sea substitute calcareous nannoplankton NP24/NP25 boundary. These three subdivisions in the Chattian of North Belgium correspond approximately to the Chattian A and B (= Eochattian) and C (= Neochattian) (De Man et al., 2010).

Although Munsterman \& Deckers (2020, this volume) have slightly modified the Mol and Weelde borehole interpretations as presented in De Man et al. (2010), it remains a valid observation that from east to west in the Belgian Campine a thickness reduction occurs affecting the Chattian A and B (Fig. 10). In the Antwerp harbour outlier (Ekeren borehole 15W0142; cf. Fig. 1) the basal part of the lower sequence is missing, maybe reflecting the progressive westwards expansion of the Chattian over the Campine but immediately to the east the complete succession of Chattian NSO zones is present.

\subsection{The correlation between the Campine Block and the Netherlands RVG}

Van Simaeys (2004a, fig. 5.6) and Van Simaeys et al. (2005) have demonstrated that three sedimentological cycles in the Veldhoven Formation in Belgium (Fig. 10) can consistently be traced laterally into the Groote Heide borehole in the Dutch RVG where the three cycles become considerably thicker and where more clayey intervals are intercalated in the sand intervals. However, different assumptions on formation boundaries affecting sampling intervals complicate comparison between different biozonations and their interpretation.

Comparison with older studies must take into account modified lithostratigraphic boundaries. In the Groote Heide type section the boundary between the new lithostratigraphic Groote Heide Formation and the Veldhoven Formation is set at 320.20 $\mathrm{m}$ (Munsterman et al., 2019, fig. 10) whereas the boundary between the Breda and Veldhoven Formations in the same borehole was located at $475 \mathrm{~m}$, i.e. $155 \mathrm{~m}$ deeper than in Van Simaeys (2004a, fig. 5.6). Hence, the expanded Veldhoven Formation sensu Munsterman et al. (2019) is half Miocene, whereas the restricted Veldhoven Formation sensu Van Simaeys (2004a) was mostly Chattian. The lithostratigraphic sequence studied by Van Simaeys in Groote Heide borehole thus excluded the Someren Member according to the revised interpretation by Munsterman et al. (2019) since at the time of sampling by Van Simaeys this unit was incorporated in the overlying-now becoming defunct-Breda Formation (see Section 6).

\section{Discussion: Sedimentary - tectonic correlation models between the Lower Rhine Graben in Germany and RVG - Campine transition in the Netherlands and Belgium}

The Rupelian-Chattian boundary in the North Sea Basin is marked by sea-level drop and erosion during the Oligocene Glacial Maximum or Oi2b-event, coinciding with the boundary between Rupelian and Chattian, followed by a rapid warming and sea-level rise accompanied by the Asterigerina Bloom (Vandenberghe et al., 1998, 2004, 2012; De Man et al., 2010). Moreover, the RVG became reactivated, resulting in an angular unconformity between Rupelian and Chattian deposits and strong Chattian thickness increase towards the graben depocenter (De Man et al., 2010). Hence, this RupelianChattian hiatus is the result of the combined effect of initial Savian tectonism and of a glacio-eustatic sea-level fall (Vandenberghe et al., 2012; see also Steurbaut, 2015). The predominant sediment type changed from clayey deep water to shallow glauconitic shelly sand, grouped in the Voort Member of the Veldhoven Formation (Vandenberghe, 1988;

\begin{tabular}{llll}
\hline Someren Member & $680-774 \mathrm{~m}$ & S\&T 2 to 4 & (Chatt C) \\
Wintelre, ex-Veldhoven Member & $774-840 \mathrm{~m}$ & S\&T 1 & (Chatt C) \\
Voort Member above gamma ray peak & $840-920 \mathrm{~m}$ & S\&T 07 to 09 & (Chatt B) \\
Voort Member gamma ray peak interval & $920-940 \mathrm{~m}$ & S\&T 06 & (Chatt A) \\
Voort Member below gamma ray peak & $940-975 \mathrm{~m}$ & S\&T 05 & (Chatt A) \\
\hline
\end{tabular}

Table 1. Lithostratigraphic subdivision of the Veldhoven Formation in the Molenbeersel borehole, with depth range and corresponding Schneider and Thiele hydrostratigraphic codes of the Lower Rhine Basin and Chattian age assignments based on correlation with type sections in the Lower Rhine coal and salt districts. 
NW

\section{$\mathrm{He} 210-{ }^{87} \mathrm{Sr} /{ }^{86} \mathrm{Sr}$ Dates
$\mathrm{Hr} 131.2-\mathrm{K}-\mathrm{Ar}$ dates}

Base Asterigerina Horizon

dates in italic and with * are considered too old

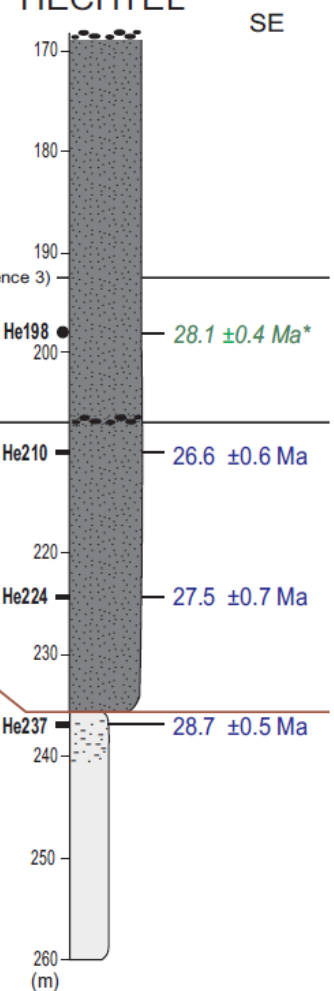

Figure 10. Schematic correlation between boreholes in the Campine Basin at the Rupelian-Chattian boundary level, with upward cut-off at the base of overlying Miocene Berchem and Bolderberg Formations, displaying Sr-isotope and K-Ar dates (reprint from De Man et al., 2010, fig. 4). Dinoflagellate data confirm the gradual thickness decrease from east to west, leading to condensation of the upper sequences. Location: profile line D on Fig. 1, note that boreholes Helchteren and Hechtel are in reverse geographical order.

Vandenberghe et al., 2012).

The Chattian subsidence pulse leading to the deposit of the Voort Sand in the Campine Basin and westerly adjoining areas was interrupted by a new uplift, corresponding to the main Savian Unconformity occurring between the OligoceneMiocene boundary and the Burdigalian, as no sediments of Aquitanian age are known outside RVG in Belgium (Vandenberghe, 2015; Louwye et al., 2020, this volume). The earliest Miocene deposits of the Antwerp Campine, namely the Edegem Sand of the Berchem Formation were considered as deposited during the Burdigalian (late Lower Miocene) (Louwye et al., 2015; Louwye et al., 2020, this volume). However, this deposit is composed of different sequences, which may be reworked from older deposits, even from timeequivalent deposits of the Veldhoven Formation, as shown by the outlier north of Antwerp. Similarly, the lithostratigraphic base of the Berchem Formation in the Antwerp Campine is set at the appearance of black glauconitic sand.

In the RVG and further north towards the North Sea depocentre, however, dinocyst biozonation in the middle and upper parts of the Veldhoven Formation indicates that this formation reaches into the Aquitanian and even Burdigalian times, thereby strongly reducing or even annihilating the gap with the succeeding Miocene formations (Munsterman et al., 2019). This means that the tectonic effect of the Savian Unconformity is more than compensated by strong subsidence of the RVG. Up to $300 \mathrm{~m}$ of Chattian sediments were preserved in this intracratonic graben, leaving few occasions for uplift and erosion. Thickness increase towards the graben centre is gradual (NITG, 2011) and spread evenly over time, resulting in almost equal thicknesses for the Chattian and Aquitanian to lower Burdigalian (or for the Voort and Wintelre to Someren Members of the Veldhoven Formation), as shown by the thickness distribution in Molenbeersel (Fig. 8). Although there is no proof of dating it can be assumed that Aquitanian deposits effectively occur in Molenbeersel and the Belgian part of RVG.

A crucial caveat is the correlation between the German lithostratigraphic subdivision, represented by the S\&T codes in the Köln Formation assigned to the Chattian, and biostratigraphic subdivision of the Chattian into the RVG. Hager et al. (1998) established lithostratigraphic correlations with subdivision according to the S\&T codes, resulting in five units in boreholes Asten and Molenbeersel (cf. Fig. 9). This would mean that the Wintelre (ex-Veldhoven) Member corresponds to S\&T 1 or base Chattian C, but in the Munsterman et al. (2019) interpretation this member reaches into the Aquitanian.

It is essential to note that the clay units identified in Molenbeersel (Belgium) and in Asten (the Netherlands) by Hager et al. (1998) are interpreted in terms of the Schneider \& Thiele units, which are defined in marginal marine to lagoonal environments associated with lignite in the Lower Rhine delta plain (see also Schäfer \& Utescher, 2014, fig. 3). Such correlation of clays across facies boundaries from the southeastern fluvial border into the deeper marine RVG (Molenbeersel-Asten boreholes) can only be tentative. However, the lateral persistence of the clayey unit within the Voort Member (corresponding to hydrostratigraphic code S\&T06 of the Lower Rhine basin) across all structural units is remarkable and useful as a stratigraphic marker. This eustasybased model is in contrast with the sedimentological model of Schäfer et al. (2005), which proposes a lateral transition from marginal facies of the Köln Formation in the southeastern blocks over the shallow marine Voort Sand in the DutchGerman boundary realm to the deeper water Veldhoven Clay in the deeper part of the RVG basin in the Netherlands. Similarly, the dynamic concept in de Mulder et al. (2003, fig. 172; Wong et al., 2007, fig. 9) suggests that the Veldhoven Clay is a deeper 
marine facies, compared to the Voort Sand and the Someren Sand. This remains an open question without proper sedimentological analysis.

\section{Conclusion: arguments for a threefold subdivision of the Veldhoven Formation in Belgium}

By the end of the Rupelian, tectonic activity increased and induced uplift and considerable erosion in the western part of the Campine Basin, while the RVG resumed strong subsidence at the beginning of the Chattian, accommodating several hundred metres of marine shallow water deposits. In the Campine Basin outside the graben rather thin Chattian sediments are only contiguously preserved on the Graben Shoulder, bordered to the west by the Rijen-Rauw-Beringen fault systems. In the Antwerp Campine further west thin, probably condensed Chattian sediments are only patchily preserved (Fig.1). Because the sedimentation rate was more continuous in the RVG during the Chattian and into the Miocene, the Veldhoven Formation spans the PaleogeneNeogene boundary. The presumably Chattian Boncelles Sand is locally preserved further to the southeast, on the eastern Ardennes and Hesbaye, due to subsidence linked with fault activity along the western border of the Lower Rhine Graben, which also allowed preservation of the Voort Sand on the Campine Block.

A proposal for lithostratigraphic subdivision of the Veldhoven Formation in three members has been submitted for discussion to the Subcommission Paleogene-Neogene of the Belgian National Commission for Stratigraphy (Discussion note about the Chattian (Upper Oligocene) lithostratigraphic units, 14.07.2015.). Further hydrostratigraphic subdivision, based on the Schneider \& Thiele coding system, could be added, although a full sedimentological understanding of their meaning in the deeper part of the basin is not yet clear.

It is preferred to follow the Dutch nomenclature for the Dutch part of the RVG because there the Veldhoven Formation has its thickest and most complete development and there its stratigraphy has been documented and studied in several boreholes, including Molenbeersel. In addition, as demonstrated in Section 4, the Chattian section of the Molenbeersel borehole and surroundings in Belgium fits in the Dutch lithostratigraphic scheme, making separate stratigraphic names superfluous. Moreover, the lower unit in the Dutch Veldhoven Formation is the Voort Member, inherited from the Chattian in Belgium.

This means that it is proposed to maintain in Belgium the following nomenclature: Veldhoven Formation, from base to top consisting of Voort, Wintelre and Someren Members.

The Veldhoven Formation is considered as the latest of the Paleogene stratigraphic units in Belgium deposited in between Savian tectonic pulses. However, the Veldhoven Formation mounts up to the Early Miocene Unconformity (EMU) redefined in the Netherlands by Munsterman et al. (2019). It is also the first formation whose depositional area and thickness distribution is controlled by active subsidence of the RVG.

The clayey interval identified within the Voort Member (i.e. 920-940 m interval in the Molenbeersel borehole), correlated with the Lower Rhine hydrostratigraphic unit S\&T 06 by Hager et al. (1998), could have a comparable sedimentological origin as the Wintelre (ex-Veldhoven) Member (i.e. 774-840 m interval in the Molenbeersel borehole), correlated with S\&T 1, as it displays a similar log signature and borehole sample description is similar. It seems that this interval within the Voort Member also occurs outside the RVG on the Campine Graben Shoulder and in the northern Antwerp Campine (Fig. 4). If proven that indeed the same horizon is involved it could become a regional correlation horizon with an appropriate rank.

\section{Acknowledgements}

The authors borrowed illustrations from Jan Walstra (Geological Survey of Belgium) for Figure 4 and from Laurent Wouters (NIRAS/ONDRAF) for Figure 6. We acknowledge the assistance of Erik Vandegehuchte (Geo-collection unit of Royal Belgian Institute of Natural Sciences) for improving Figure 1 and of Marleen De Ceukelaire (RBINS Geo-collection manager) and Katrien De Nil (VPO) for borehole data and conversion numbers. Jef Deckers (VITO) is sincerely thanked for discussions on earlier versions of the paper that improved it but obviously the present authors remain solely responsible for the opinions expressed. The reviewers Johan Matthijs and Stefaan Van Simaeys are thanked for their appreciated efforts to increase the coherency of this manuscript.

\section{References}

Ancion, Ch. \& Van Leckwijck, W., 1947. Les sables de la région de Liège. In Centenaire de l'Association des Ingénieurs sortis de l'Ecole de Liège (A.I.Lg.): Congrès 1947, Section Géologie. A.I.Lg., Liège, 187-191.

Anderson, A.J., 1961. Gliederung und paläogeographische Entwicklung der Chattischen Stufe (Oberoligozän) in Nordseebecken. Meyniana $10,118-146$

Anderson, H.-J., Hinsch, W., Martini, E., Muller, C. \& Ritzkowski, S. 1971, Chattian. In Carloni, G.C., Marks, P., Rutsch, R.F. \& Selli, R. (eds), Stratotypes of Mediterranean Neogene Stages. Giornale di geologia, ser. 2, 37, 69-80.

Broothaers, M., Deckers, J., Lagrou, D. \& Matthijs, J., 2012. 3Dlagenmodel van de Tertiaire afzettingen in de Roerdalslenk in Vlaanderen. VITO, Mol, VITO-rapport 2012/SCT/R/191, 58 p.

Buffel, P., Claes, S. \& Gullentops, F., 2001. Toelichtingen bij de geologische kaart van België, Vlaams Gewest: kaartblad 26, Rekem [ $1 / 50$ 000]. Belgische Geologische Dienst en Ministerie van de Vlaamse Gemeenschap, Afdeling Natuurlijke Rijkdommen en Energie, Brussel, 56 p.

Calembert, L. \& Gulinck, M., 1954. L'Oligocène. In Fourmarier, P. (ed.), Prodrome d'une description géologique de la Belgique. Société géologique de Belgique, Liège, 495-532.

Claes, S., Frederickx, E. \& Gullentops, F., 2001. Toelichtingen bij de geologische kaart van België, Vlaams Gewest: kaartblad 34 [ - 35 42], Tongeren [1/50 000]. Belgische Geologische Dienst en Ministerie van de Vlaamse Gemeenschap, Afdeling Natuurlijke Rijkdommen en Energie, Brussel, 55 p.

Coetsiers, M., Van Camp, M. \& Walraevens, K., 2014. Neogeen pakket van watervoerende lagen (Mioceen, Plio-Pleistoceen, Complex van de Kempen). In Dassargues, A. \& Walraevens, K., Watervoerende lagen \& grondwater in België / Aquifères \& eaux souterraines en Belgique. Academia Press, Gent, 59-70.

Cornélis, B., Wouters, L., Cool, W., Lalieux, Ph., Gens, R. \& De Preter, P., 2001. Technical overview of the SAFIR 2 report. Safety Assessment and Feasibility Interim Report 2. ONDRAF/NIRAS, NIROND 2001-05 E, 268 p.

Deckers, J., 2016. The Late Oligocene to Early Miocene early evolution of rifting in the southwestern part of the Roer Valley Graben. International Journal of Earth Sciences (Geologische Rundschau), 105, 1233-1243. https://doi.org/10.1007/s00531-015-1236-5

Deckers, J. \& Louwye, S., 2019. A reinterpretation of the ages and depositional environments of the lower and middle Miocene stratigraphic records in a key area along the southern margin of the North Sea Basin. Geological Magazine, 156/3, 525-532. https:// doi.org/10.1017/S0016756817000991

Deckers, J. \& Munsterman, D., 2020. Middle Miocene depositional evolution of the central Roer Valley Rift System. Geological Journal, 55, 6188-6197. https://doi.org/10.1002/gj.3799

Deckers, J., Vernes, R., Dabekaussen, W., Den Dulk, M., Doornenbal, H., Dusar, M., Hummelman, J. Matthijs, J., Menkovic, A., Reindersma, R., Walstra, J., Westerhoff, W. \& Witmans, N., 2014 
Geologisch en hydrogeologisch 3D model van het Cenozoïcum van de Roerdalslenk in Zuidoost-Nederland en Vlaanderen (H3O Roerdalslenk). Studie uitgevoerd in opdracht van de Afdeling Land en Bodembescherming, Ondergrond, Natuurlijke Rijkdommen van de Vlaamse Overheid, de Afdeling Operationeel Waterbeheer van de Vlaamse Milieumaatschappij, de Nederlandse Provincie Limburg, de Nederlandse Provincie Noord-Brabant, TNOGeologische Dienst Nederland, VITO/Energyville, in samenwerking met de Belgische Geologische Dienst. VITO-rapport 2014/ETE/R/1, 205 p.

Deckers, J., De Koninck, R., Bos, S., Broothaers, M., Dirix, K., Hambsch, L., Lagrou, D., Lanckacker, T., Matthijs, J., Rombaut, B., Van Baelen, K. \& Van Haren, T., 2019. Geologisch (G3Dv3) en hydrogeologisch (H3D) 3D-lagenmodel van Vlaanderen. Studie uitgevoerd in opdracht van het Vlaams Planbureau voor Omgeving (Departement Omgeving) en de Vlaamse Milieumaatschappij, Eindrapport. VITO, Mol, VITO-rapport 2018/RMA/R/1569, 286 p.

de Lang, F.D., 2003. Beschrijving lithostratigrafische eenheid: Veldhoven Formatie. Nederlands Instituut voor Toegepaste Geowetenschappen -TNO.

De Man, E., Van Simaeys, S., Vandenberghe, N., Harris, W.B. \& Wampler, J.M., 2010. On the nature and chronostratigraphic position of the Rupelian and Chattian stratotypes in the southern North Sea basin. Episodes, 33/1, 3-14. https://doi.org/10.18814/ epiiugs/2010/v33i1/002

Demoulin, A., 1989. Les transgressions oligocènes sur le massif Ardenne-Eifel. Annales de la Société géologique de Belgique, 112, 215-224.

de Mulder, E.F.J., Geluk, M.C., Ritsema, I.L., Westerhof, W.E. \& Wong, T.E. (eds), 2003. De ondergrond van Nederland. Wolters Noordhoff, Groningen, $379 \mathrm{p}$.

Demyttenaere, R., 1989. The post-Paleozoic geological history of northeastern Belgium. Academiae Analecta, Mededelingen van de Koninklijke Academie voor Wetenschappen, Letteren en Schone Kunsten in België, Klasse der Wetenschappen, 51/4, 51-81.

Demyttenaere, R. \& Laga, P., 1988. Breuken- en isohypsenkaarten van het Belgisch gedeelte van de Roerdal Slenk : eerste resultaten van een seismisch onderzoek in het gebied van Poppel - Lommel Maaseik. Geologische Dienst van België, Professional Paper, 1988/4, 234, $20 \mathrm{p}$.

Destinez, P., 1909. Comparaison de la faune des sables de Boncelles avec celle de l'Oligocène supérieur de Westphalie. Annales de la Société géologique de Belgique, 36, M47-M50.

Fourmarier, P., 1920. A propos de l'âge des sables tertiaires des environs de Liége. Annales de la Société géologique de Belgique, 43, B164-B168.

Fourmarier, P., 1934. Observations nouvelles sur les dépôts tertiaires des environs de Liége. Annales de la Société géologique de Belgique, 57, B178-B189.

Fuchs, T., 1894. Tertiärfossilien aus den kohlenführenden Miocänablagerungen der Umgebung von Krapina und Radaboj und über die Stellung der sogenannten "Aquitanischen Stufe". Königlich -Ungarische Geologische Anstalt, Mittheilungen und Jahrbuch, 10/5, 163-175.

Geluk, M.C., Duin, E.J.Th., Dusar, M., Rijkers, R.H.B., van de Berg, M.W. \& van Rooijen, P., 1994. Stratigraphy and tectonics of the RVG. Geologie en Mijnbouw, 73, 129-141.

Gibbard, P.L. \& Lewin, J., 2016. Filling the North Sea Basin: Cenozoic sediment sources and river styles. Geologica Belgica, 19, 201-217. http://dx.doi.org/10.20341/gb.2015.017

Gulinck, M., 1960. Borehole description 015W014. Archieven Belgische Geologische Dienst. http://collections.naturalsciences.be/ ssh-geology-archives/arch/015w/015w0142.txt, accessed 04/06/2020.

Hager, H., Vandenberghe, N., van den Bosch, M., Abraham, M., von der Hocht, F., Rescher, K., Laga, P., Nickel, E., Verstraelen, A., Leroi, S. \& van Leeuwen, R.J.W., 1998. The geometry of the Rupelian and Chattian depositional bodies in the Lower Rhine district and its border area: implications for Oligocene lithostratigraphy. Bulletin of the Geological Society of Denmark, 45, 53-62.
Halet, F., 1920. La géologie tertiaire de la Campine anversoise et limbourgeoise: 1. La falaise d'Elsloo et son gravier fossilifère. Bulletin de la Société belge de Géologie, de Paléontologie et d'Hydrologie, 30, 84-100.

Halet, F., 1936. Le Néogène et l'Oligocène entre Hasselt et Genk. Bulletin de la Société belge de Géologie, de Paléontologie et d'Hydrologie, 46, 194-199.

Hinsch, W., 1956. Lexique Stratigraphique International, Vol. 1, Europe. Fascicule 5, Allemagne; $5 \mathrm{~h} \mathrm{1}$, Tertiaire Allemagne du Nord. Centre National de la Recherche Scientifique, Paris, 75 p.

Hörnes, G., 1853. Mitteilung an Prof. Bronn gerichtet: Wien, 3. Okt.1853. Neues Jahrbuch der Mineralogie, Geologie und Geognosie der Petrefaktenkunde, 1853, 806-810.

Laga, P., 1974. Interpretation borehole Ekeren. Archieven Belgische Geologische Dienst. http://gisel.naturalsciences.be/data/ text/015W/015W0142, accessed 04/06/2020.

Laga, P., 1976. Geologische Doorsneden. Archieven Belgische Geologische Dienst. http://collections.naturalsciences.be/sshgeology/geology/profiles-neogeen2020, accessed 04/06/2020.

Laga, P., Louwye, S. \& Geets, S., 2001. Paleogene and Neogene lithostratigraphic units (Belgium). Geologica Belgica, 4, 135-152. https://doi.org/10.20341/gb.2014.050

Leriche, M., 1922. Le terrain wealdien et les terrains tertiaires de l'Ardenne française. L'Ardenne pendant l'ère tertiaire. Bulletin de la Société belge de Géologie, de Paléontologie et d'Hydrologie, 35, 68-81.

Letsch, W.J. \& Sissingh, W., 1983. Tertiary stratigraphy of the Netherlands. Geologie en Mijnbouw, 62, 305-318.

Lie, S.F., 1983. Seismic survey Neeroeteren-Rotem 1980-1981 (Campine, Belgium). Stratigraphic and structural interpretation of a Tertiary-Cretaceous sedimentary rock sequence. KU Leuven Mijnbouw (eindverhandeling), Leuven, 147 p.

Louwye, S., Laga, P. \& Herman, J., 2015. Het Mioceen. In Borremans, M. (ed.), Geologie van Vlaanderen. Academia Press, Gent, 155-164.

Louwye, S., Deckers, J., Verhaegen, J., Adriaens, R. \& Vandenberghe, N., 2020. A review of the lower and middle Miocene in northern Belgium. Geologica Belgica, 23/3-4, this volume. https:// doi.org/10.20341/gb.2020.010

Matthijs J., 1999. Toelichtingen bij de geologische kaart van België, Vlaams Gewest: kaartblad 25, Hasselt [1/50 000]. Belgische Geologische Dienst en Ministerie van de Vlaamse Gemeenschap, Afdeling Natuurlijke Rijkdommen en Energie, Brussel, 104 p.

Matthijs, J., Deckers, J., Broothaers, M \& De Koninck, R., 2016. A new lithostratigraphic and seismostratigraphic interpretation of the Cenozoic strata for the Molenbeersel well (049W0226) in the Roer Valley Graben, NE Belgium. In Proceedings of the $5^{\text {th }}$ International Geologica Belgica Congress, 26-29 January 2016, University of Mons, Mons, Belgium, p. 259.

Mayer-Eymar, K., 1858. Versuch einer neuen Klassifikation der TertiärGebilde Europa's. Verhandlungen der Schweizerischen Naturforschenden Gesellschaft, Johrsversammeln in Trogen, 17-19 August 1857. Tabell, Basel, 70-71 \& 165-199.

Munsterman, D.K. \& Deckers, J., 2020. The Oligocene/Miocene boundary in the ON-Mol-1 and Weelde boreholes along the southern margin of the North Sea Basin, Belgium. Geologica Belgica, 23/3-4, this volume. https://doi.org/10.20341/gb.2020.007

Munsterman, D.K., ten Veen, J.H., Menkovic, A., Deckers, J., Witmans, N., Verhaegen, J., Kerstholt-Boegehold, S.J., van de Ven, T. \& Busschers, F.S., 2019. An updated and revised stratigraphic framework for the Miocene and earliest Pliocene strata of the RVG and adjacent blocks. Netherlands Journal of Geosciences, 98, e8. https://doi.org/10.1017/njg.2019.10

NAM \& RGD, 1980, Stratigraphic nomenclature of the Netherlands. Verhandelingen van het Koninklijk Nederlands GeologischMijnbouwkundig Genootschap, Geologische serie, 32, 1-77.

NITG, 2001. Geological atlas of the subsurface of the Netherlands (1:250.000). Explanation to map sheets XIII and XIV BredaValkenswaard and Oss-Roermond. Netherlands Institute of Applied Geoscience - TNO, Utrecht, 149 p. 
Ringelé, A., 1974. Bijdrage tot de systematiek, de evolutie en de paleoekologie van Bivalvia uit Neogene afzettingen van Noord-België. Unpublished Ph.D. Thesis, Katholieke Universiteit Leuven, Leuven, Part II, 1-107.

Rossa, H.G., 1986. Upper Cretaceous and Tertiary inversion tectonics in the western part of the Rhenish-Westphalian coal district (FRG) and in the Campine area (N Belgium). Annales de la Société géologique de Belgique, 109, 367-410

Rutot, A., 1907. Un grave problème; une industrie humaine datant de l'époque oligocène : comparaison avec les outils tasmaniens actuels. Bulletin de la Société belge de Géologie, de Paléontologie et d'Hydrologie, 21, M439-M482.

Schäfer, A. \& Utescher, T., 2014. Origin, sediment fill, and sequence stratigraphy of the Cenozoic Lower Rhine Basin (Germany) interpreted from well logs. German Journal of Geoscience, 165, 287 314. https://doi.org/10.1127/1860-1804/2014/0062

Schäfer, A., Utescher, T., Klett, M. \& Valdivia-Manchego, M., 2005. The Cenozoic Lower Rhine Basin - rifting, sediment input, and cyclic stratigraphy. International Journal of Earth Sciences (Geologische Rundschau), 94, 621-639. https://doi.org/10.1007/ s00531-005-0499-7

Schmitz, G. \& Stainier, W., 1909. Découverte en Campine de l'Oligocène supérieur marin: la question de l'âge du Boldérien de Dumont. Annales de la Société géologique de Belgique, 36, M253-M367.

Schneider, H. \& Thiele, S., 1965. Geohydrologie des Erftgebietes. Ministerium für Ernährung, Landwirtschaft und Forsten Land Nordrhein-Westfalen, Düsseldorf, 185 p.

Stainier, X., 1911. Sur les recherches de sel en Campine. Annales des Mines de Belgique, 16, 117-170.

Stainier, X. 1929. Les plissements du Tertiaire supérieur belge première note. Bulletin de la Société belge de Géologie, de Paléontologie et d'Hydrologie, 37, 149-198.

Steurbaut, E., 2015. Opmars van de zoogdieren en prelude van het heden. In Borremans, M. (ed.), Geologie van Vlaanderen. Academia Press, Gent, 105-116.

TNO-GSN, 2018a. Veldhoven Formation. In Stratigraphic Nomenclature of the Netherlands. TNO - Geological Survey of the Netherlands. http://acc.dinoloket.nl/en/stratigraphic-nomenclature/ veldhoven-formation, accessed 09/06/2020.

TNO-GSN, 2018b. Wintelre Member. In Stratigraphic Nomenclature of the Netherlands. TNO - Geological Survey of the Netherlands. https://acc.dinoloket.nl/en/stratigraphic-nomenclature/wintelremember, accessed 04/06/2020.

TNO-GSN, 2020. Wintelre Member. In Stratigraphic Nomenclature of the Netherlands, TNO - Geological Survey of the Netherlands. http://www.dinoloket.nl/en/stratigraphic-nomenclature/wintelremember, accessed on 27/12/2020.

van Adrichem Boogaert, H.A. \& Kouwe, W.F.P. (eds), 1997. Stratigraphic nomenclature of the Netherlands, revision and update by RGD and NOGEPA. Mededelingen Rijks Geologische Dienst, 50, Section I, Tertiary, $39 \mathrm{p}$.

Vancampenhout, P., 2004. Opmaak Isohypsenkaarten van het Tertiair in Vlaanderen : Eindrapport, in opdracht van het Ministerie van de Vlaamse Gemeenschap - Afdeling Natuurlijke Rijkdommen en Energie. Belgische Geologische Dienst, Brussel, 121 p.

Vandenberghe, N., 1988. Formatie van Voort. In Maréchal, R. \& P. Laga (ed.), Voorstel lithostratigrafische indeling van het Paleogeen. Nationale Commissies voor stratigrafie, commissie: Tertiair. Belgische Geologische Dienst, Brussel, 206-207.

Vandenberghe, N., 2015. Het Oligoceen. In Borremans M. (ed.), Geologie van Vlaanderen. Academia Press, Gent, 147-154.

Vandenberghe, N., 2017. Ernest Van den Broeck medallist lecture 2016. Tectonic and climatic signals in the Oligocene sediments of the Southern North-Sea Basin. Geologica Belgica, 20/3-4, 105-123. http://dx.doi.org/10.20341/gb.2017.007

Vandenberghe, N., Hilgen, F.J. \& Speijer, R.P., 2012. The Paleogene Period. In Gradstein, F.M., Ogg, J.G., Schmitz, M.D., Ogg, G.M. (eds), The Geologic Time Scale 2012, Vol. 2. Elsevier, Amsterdam, 855-921.
Vandenberghe, N., Laga, P., Steurbaut, E., Hardenbol, J. \& Vail, P. R., 1998. Tertiary sequence stratigraphy at the southern border of the North Sea Basin in Belgium. In de Graciansky, P.-C., Hardenbol, J., Jacquin, T. \& Vail, P.R. (eds), Mesozoic and Cenozoic Sequence Stratigraphy of European Basins. SEPM Special Publication, 60, 119-154. https://doi.org/10.2110/pec.98.02.0119

Vandenberghe, N., Van Simaeys, S., Steurbaut, E., Jagt, J.W.M. \& Felder, P.J., 2004. Stratigraphic architecture of the Upper Cretaceous and Cenozoic along the southern border of the North Sea Basin in Belgium. Netherlands Journal of Geosciences / Geologie en Mijnbouw, 83, 155-171. https://oi.org/10.1017/ S0016774600020229

Van den Broeck, E., 1893. Coup d'œil synthétique sur l'Oligocène belge et observations sur le Tongrien supérieur du Brabant. Bulletin de la Société belge de Géologie, de Paléontologie et d'Hydrologie, 7, 208-302.

Van Simaeys, S., 2004a. Stratigraphic and paleoenvironmental analysis of the Rupelian and Chattian in their type regions: implications for global Oligocene chronostratigraphy. Unpublished Ph.D. Thesis, Geo-Institute, KU Leuven, Leuven, 201 p.

Van Simaeys, S., 2004b. The Rupelian-Chattian boundary in the North Sea Basin and its calibration to the international time-scale. Netherlands Journal of Geosciences / Geologie en Mijnbouw, 83/3, 241-248. https://doi.org/10.1017/S0016774600023532

Van Simaeys, S., Munsterman, D. \& Brinkhuis, H., 2005. Oligocene dinoflagellate cyst biostratigraphy of the southern North Sea Basin. Review of Palaeobotany and Palynology, 134, 105-128. https:// doi.org/10.1016/j.revpalbo.2004.12.003

Van Straelen, V., 1923. Observations sur le Néogène et l'Oligocène en profondeur dans la Campine Limbourgeoise. Bulletin de la Société belge de Géologie, de Paléontologie et d'Hydrologie, 33, 58-65.

Verbeek, J.W., de Leeuw, C.S., Parkern N. \& Wong, Th.E., 2002. Characterisation and correlation of Tertiary seismostratigraphic units in the Roer Valley Graben. Netherlands Journal of Geosciences / Geologie en Mijnbouw, 81, 159-166. https:// doi.org/10.1017/S0016774600022393

Vernes, R.W., Deckers, J., Bakker, M.A.J., Bogemans, F., De Ceukelaire, M., Doornenbal, J.C., den Dulk, M., Dusar, M., Van Haren, T.F.M., Heyvaert, V.M.A., Kiden, P., Kruisselbrink, A.F., Lanckacker, T., Menkovic, A., Meyvis, B., Munsterman, D.K., Reindersma, R., Rombaut, B., ten Veen, J.H., van de Ven, T.J.M., Walstra, J. \& Witmans, N., 2018. Geologisch en hydrogeologisch 3D model van het Cenozoïcum van de Belgisch-Nederlandse grensstreek van MiddenBrabant / De Kempen (H3O - De Kempen). TNO-rapport TNO 2017 R11261 - VITO 2017/RMA/R/1348, 109 p.

Weerts, H.J.T., Cleveringa, P., Ebbing, J.H.J., de Lang, F.D. \& Westerhoff, W.E., 2003. De lithostratigrafische indeling van Nederland. Formaties uit het Tertiair en Kwartair. Rept. Nr. 03-051A. Nederlands Instituut voor Toegepaste Wetenschappen TNO, Utrecht, $38 \mathrm{p}$.

Wong, Th.E., de Lugt, I.R., Kuhlmann, G. \& Overeem, I., 2007. Tertiary. In Wong, Th.E., Batjes, D.A.J. \& de Jager, J. (eds), Geology of the Netherlands. Royal Netherlands Academy of Arts and Sciences (KNAW), Amsterdam, 151-171.

Wouters, L., Mertens, J. \& Moermans, G., in prep. Seismic reconnaissance campaigns in the vicinity of the Mol-Dessel nuclear zone (Campine Basin). VITO, Mol, NIROND-TR 2014-01.

Manuscript received 04.09.2020, accepted for publication 07.11.2020, available online 30.12.2020 